\title{
FORAMINIFERAL BIOSTRATIGRAPHY AND CORRELATIONS IN THE GULF OF ALASKA TERTIARY PROVINCE
}

\author{
By \\ W. W. Rau, George Plafker, and G. R. Winkler
}

\section{INTRODUCTION}

As part of ongoing research by the U.S. Geological Survey on the geology and resource potential of the Gulf of Alaska Tertiary Province, a vast amount of data has been accumulated over the past 25 years on the lithology and paleontology of bedded rocks in the province. This report brings together available information on the occurrence, age, and paleoecological significance of benthonic foraminifers and presents correlations based on these data from 16 measured stratigraphic sections and 12 exploratory wells. Relatively few reports employing modern taxonomic methods developed during the past 40 years have been published on foraminiferal biostratigraphy of the Gulf of Alaska. Reports by Cushman (1941), Cushman and Todd (1947), Tappan (1951), Todd (1953), Loeblich and Tappan (1953), Todd (1957), Rau (1963), Cooper (1964), and Todd and Low (1967) are primarily concerned with taxonomy, ecology and paleoecology, or the geologic age of assemblages from isolated outcrops. Almost no data have been published on foraminiferal correlations of measured sections and wells. Thus, the paucity of such information has prompted the synthesis and interpretation of foraminiferal data that provide the framework of correlation presented in this report. Some of the benthonic provincial stages that have been assigned to lower and middle parts of the Tertiary of other west coast areas are recognized for the Gulf of Alaska. Divisions for the upper part of the Tertiary are broad, but specific faunal occurrences are recognized as possible aids to correlations. Regional correlations presented in this report are necessarily broad and may be modified and refined when new data become available from the current round of exploratory drilling for petroleum in the offshore part of the Gulf of Alaska Tertiary Province.

It is anticipated that this report will be of particular interest to readers associated with petroleum exploration. As a convenience to them and because most foraminiferal data from wells, including those of this report, are from cuttings, all checklists are arranged to show plainly the highest occurrence of each species within each measured section and well. Furthermore, in conformity with these data, all sections and wells are described from the top to bottom. The text describes the stratigraphic and paleoecologic significance of foraminifers by biostratigraphic units and by individual sections and wells.

A comparable synthesis of marine molluscan data from the measured sections (Addicott, Winkler, and Plafker, 1978) may be used to compare and evaluate the suggested correlations as based independently on the microfauna or the macrofauna.

\section{ACKNOWLEDGMENTS}

The unpublished pioneer studies and interagency reports of a number of micropaleontologists have contributed much to this report. Among these are the late Patsy J. Smith, Helen Tappan Loeblich, and particularly Ruth Todd and Doris Low, who not only made many of the early reports on foraminifors from wells and surface sections but also prepared numerous faunal slides. These slides, together with their reports, have served as the primary base for species identification. Their interpretations on species have been followed largely in our integration of materials from other workers. Most of the material available to the U.S. Geological Survey for this study was from measured stratigraphic sections and cuttings and some cores from wells drilled on Federal lands. In addition, all foraminif ral material from wells on file at the Alaska State Division of Oil and Gas core library in Anchorage was examined for this synthesis. Plafker and Winkler fumished the stratigraphic data and collected many of the samples; the micropaleontology and correlations were done by Rau. Susan J. Hunt provided careful drafting and editing assistance. Constructive technical suggestions were made by $\mathrm{W}$. $\mathrm{O}$. Addicott and P. J. Quinterno.

\section{SOURCES AND RELIABILITY OF DATA}

The foraminiferal data presented in this report come from a variety of sources. Although we endeavored to interpret and synthesize these data consistently, the accuracy and reliability of our conclusions, particularly between wells, vary as indicated below.

Three basic kinds of information are represented herein. (1) Faunal data for wells 12, and 14-17 are summarized from a brief examination of cuttings and faunal slides made from cuttings on file in Anchorage, Alaska, at the State Division of Oil and Gas core library. Names used on the checklists for these wells represent tentative identifications made with out the aid of illustrated publications or type material. Materials on file in Anchorage from wells 2 and 22 were also examined, but additional slides and faunal lists made by other worl ?rs were available for more careful study. (2) For wells 23-25, only faunal lists prepared by other workers were available for study. Some names have been changed to conform with species concepts used in this report. In the checklists, these names are among those preceded by a query, indicating uncertainty of identification. No checklist has been prepared for well 25 because so little data were available. (3) For each measured section (except 28 and 30, for which no foraminiferal data are available) and for all wells not included above, faunal slides were available for detailed study with $\mathrm{com}$ parative materials and publications.

\section{SUMMARY OF FAUNAL CHARACTERISTICS BY BIOSTRATIGRAPHIC UNIT \\ CRETACEOUS ROCKS}

Although Cretaceous biostratigraphy in the Gulf of Ala ska is beyond the scope of this report, Early Cretaceous faunas are reported here from the lower part of the Yakutat \#3 well and Late Cretaceous faunas from both the Yakutat \#2 and \#3 wells (checklists 23 and 24, sheet 3 ) 
LOWER AND MIDDLE EOCENE ROCKS, PENUTIAN (?) AND ULATISIAN STAGES, UNDIFFERENTIATED

Tertiary assemblages believed to be older than those of the Narizian Stage are recorded from approximately the lower 1,500 feet of the Middleton Island \#1 well (checklist 2 , sheet 1 ). Although our studies of this well are based on limited original material, we conclude that an age no younger than the Ulatisian Stage is reasonably certain. The maximum age of these assemblages is less certain, but probably they are no older than the Penutian Stage.

Cold water conditions and bathyal depths are suggested by these assemblages. Particularly diagnostic are several species of Pullenia, several arenaceous species, and representatives of Allomorphina and a small Eponides. Furthermore, most of the species are dwarfed, perhaps suggesting adverse environmental conditions.

\section{UPPER EOCENE ROCK, NARIZIAN STAGE ${ }^{1}$}

The Narizian Stage is recognized in several stratigraphic sections of the Kayak Island area and in wells of the Yakutat area. The following forms in these areas are regarded as typically Narizian:
Anomalina garzaensis
Bulimina schencki
Cibicides haydoni
Cibicides mcmastersi
Cibicides natlandi

Globocassidulina globosa
Gyroidina simiensis
Lenticulina welchi
Quinqueloculina goodspeedi

Cibicides natlandi, Gyroidina simiensis, Lenticulina welchi, and Quinqueloculina goodspeedi are recognized in west coast areas of the conterminous United States as important indicators of the Narizian Stage and appear to be confined to strata here regarded as Narizian in age.

Outer shelf to upper bathyal depths are suggested by the occurrence of several species of Cibicides, Lenticulina, Quinqueloculina, and small buliminids, together with other taxa that collectively suggest, moderate water depths.

\section{UPPER EOCENE ROCKS, REFUGIAN STAGE}

The Refugian Stage is recognized in a number of surface sections and wells from the Middleton Island area nearly to Icy Bay. The Refugian Stage has been regarded variously as early Oligocene, late Eocene and early Oligocene, or late Eocene in age. Currently most west coast biostratigraphers favor a late Eocene age for the entire stage and we have employed this usage.

Because many species are common to both the Refugian and Zemorrian Stages, it is not always possible to differentiate clearly these stages, particularly when key taxa are missing. Furthermore some species occur together in several of the sections and wells of this report that are not known to occur together in these stages on the west coast of the conterminous United States. Faulting could account for some of the anomalous occurrences, or the stratigraphic range for some species may differ in the two areas. In wells, such occurrences could result from contamination of cuttings by caving or recycling of drilling mud. However, in sections and wells in the Gulf of Alaska where the Refugian Stage is recognized as a distinct biostratigraphic unit, the following species typical of the Refugian Stage in the conterminous United States are important in the recognition of the stage in Alaska:

\footnotetext{
${ }^{1}$ Currently some workers are placing essentially all of the Narizian Stage in the middle Eocene (Armentrout, 1981). In order that conformity be maintained with past usage we have chosen to place the stage in the upper Eocene.
}

\section{Bulimina schencki \\ Bulimina sculptilis laciniata \\ Cassidulina galvinensis \\ Cibicides haydoni \\ Cibicides hodgei \\ Eponides mexicanus
Plectofrondicularia
packardi packardi
Uvigerina atwilli
Uvigerina cocoaensis
Valvulineria willapaensis}

Elphidium cf. E. californicum

None of these species is known to range into the Zemorrian Stage; however, all but the following four species occur in the subjacent Narizian Stage:

Cassidulina galvinensis Uvigerina atwilli

Elphidium cf. $E$. californicum

On the basis of proprietary data, other workers reportedly have recgonized subdivisions of the Refugian Stage in the Gulf of Alaska Tertiary Province; our data do not permit this refinement. Elements of both the Sigmomorphina schencki Zone and Cassidulina galvinensis Zone of Washington State (Rau, 1958,1966 ) have been observed, but they do not occur consistently in their normal stratigraphic sequence.

Cold and deep water conditions are suggested by most Gulf of Alaska Refugian assemblages. Costate buliminids and uvigerinids together with Plectofrondicularia packardi packardi, Melonis pompilioides, Gyroidina soldanii, and Globocassidulina globosa are significant cold, deep water taxa that are present in many of these Refugian assemblages. The occasional occurrence of shallower water forms such as Elphidium cf. E. californicum and Quinqueloculina imperialis suggest that, at times at least, depths were shallower.

\section{OLIGOCENE ROCKS, ZEMORRIAN STAGE}

Zemorrian assemblages typically contain species that are also known either in the subjacent Refugian Stage or overlying Saucesian Stage. The more significant species occurring in the sections and wells of this report are:

$\begin{array}{ll}\begin{array}{l}\text { Anomalina } \\ \text { californiensis }\end{array} & \begin{array}{c}\text { Elphidium cf. } E . \\ \text { minutum }\end{array} \\ \text { Buccella mansfieldi } & \text { Florilus incisum } \\ \text { oregonensis } & \text { Gyroidina soldanii } \\ \text { Cassidulinoides sp. } & \text { Sphaeroidina variabilis } \\ \text { Cassidulina } & \text { Valvulineria menloensis } \\ \text { crassipunctata } & \\ \text { Cibicides elmaensis } & \end{array}$

None of these species is restricted to the Zemorrian Stage, but either Anomalina californiensis, Buccella mansfieldi oregonensis, or Florilus incisum is usually present in Zemorrian assemblages.

Cold temperatures and middle or upper bathyal depths are suggested by Zemorrian foraminifers of the Gulf of Alaska such as Anomalina californiensis and several species of Cibicides and Gyroidina.

\section{LOWER AND MIDDLE MIOCENE ROCKS, SAUCESIAN AND RELIZIAN STAGES, UNDIFFERENTIATED}

Saucesian and Relizian foraminiferal assemblages, herein assigned to the lower and middle Miocene, are from the Middleton Island well and from wells and stratigraphic sections in the area between Kayak Island and Icy Bay.

Although most of these faunas are referred to the Saucesian Stage, others cannot be distinguished from Relizian assemblages and therefore they have been referred to the Saucesian and Relizian Stages, undifferentiated.

Perhaps the most significant element common to many of these assemblages is the presence of siphogenerinids. Siphogenerina kleinpelli has been recorded most frequently, but $S$. branneri and $S$. transuersa also occur in some of the 
samples. Apparently species of Siphogenerina have their highest occurrence in this faunal division. In addition, the following species occur with varying frequency and either singularly or collectively are supporting evidence for a Saucesian or Relizian age.

$\begin{array}{cl}\text { Bolivina marginata } & \text { Rotalia becki } \\ \text { adelaidana } & \text { ?Uvigerina californica } \\ \text { Bulimina inflata } & \text { Uvigerinella obesa } \\ \text { alligata } & \text { impolita } \\ \text { Dentalina quadrulata } & \text { ?Valvulineria araucana }\end{array}$

Epistominella parva

Although the following foraminifers are most characteristic of upper Miocene and Pliocene rocks in the Gulf of Alaska, a few also occur in Saucesian and Relizian assemblages:
Anomalina glabrata
Nonionella miocenica
Melonis pompilioides
Sphaeroidina variabilis

Melonis zaandamae

Cassidulina crassiformis, Cibicides elmaensis var. A, and Cassidulinoides $\mathrm{sp}$., although generally more significant in stratigraphically lower assemblages, range upward into the Miocene and occur in some of the Saucesian and Relizian samples.

The preponderance of faunal evidence strongly suggests cold water, bathyal conditions during Saucesian and Relizian time. The occurrence of particularly deep-water foraminifers, such as Melonis pompilioides and siphogenerinids together with costate uvigerinids and buliminids, suggests middle and perhaps even lower bathyal depths. However, a few shallowwater forms such as Nonionella miocenica, Rotalia becki, and others suggest that, on occasion, either somewhat shallower (upper bathyal) depths may have prevailed or some of the foraminifers were displaced from shallower depths.

\section{UPPER MIOCENE AND PLIOCENE ROCKS, UNDIFFERENTIATED}

This broad and obviously overlapping division includes those assemblages thought to be older than the Pleistocene but no older than the late Miocene. The available data for this division are from sections and wells mostly in the Yakataga area.

Two of the most characteristic foraminifers in these assemblages are here referred to as Melonis zaandamae and Anomalina cf. A. glabrata. The first of these taxa has been referred to by other workers variously as Nonion pompilioides (Fichtel and Moll), N. barleeanum (Williamson), and $N$. affinis (Reuss), and the second as Gyroidina condoni (Cushman and Schenck). These species rarely occur in large numbers. Undifferentiated late Miocene and Pliocene assemblages are further characterized by the sporadic occurrence of Virgulina sp., several species of costate Uvigerina, and Cibicides mckannai. Epistominella pacifica occasionally occurs in substantial numbers. Cassidulina tortuosa occurs consistently and in places in large numbers. Elphidium clavatum, Cassidulina californica, and Buccella frigida also occur sporadically in small numbers.

Foraminiferal faunas suggest that during the late Miocene and Pliocene, middle to outer shelf depths generally prevailed, but perhaps at times, particularly during earliest deposition, depths were as great as that of the upper slope (upper bathyal). The substantial numbers of Epistominella pacifica suggest fairly deep water. Water temperatures were probably cool because cold-water taxa such as Elphidium clavatum, Buccella frigida, and small cassidulinids are present, although in smaller numbers than in assemblages from younger rocks.

\section{PLIOCENE AND PLEISTOCENE ROCKS}

Pliocene and Pleistocene rocks in the Riou Bay \#1 well (18) and the La Perouse Glacier section (29) have been dif- ferentiated on the basis of foraminifers. Pliocene and Pleistocene faunas from all other sections and wells are undifferentiated, but are distinguishable from assemblages of older rocks. The following species are generally commor or occur consistently in Pliocene and Pleistocene samf'es throughout the province:

\section{Cassidulina tortuosa Elphidium clavatum}

Cassidulina californica Elphidium bartletti

Additional species either common or occurring consistently in Pliocene and Pleistocene samples of local areas inclute:

Cassidulina teretis Elphidiella groenlandica

Cassidulina islandica Elphidiella nitida

Although generally uncommon, the following species occur sporadically in Pliocene and Pleiostocene samples:

Buccella frigida Florilus labradoricus

Elphidiella oregonensis Quinqueloculina aknerianc

Epistominella pacifica

In the six stratigraphic sections in which Elphidiella nit $\mathrm{fa}$ occurs, and the one section in which Elphidium frigidum occurs, both species are either restricted to or at least noticea bly more common in the Pleistocene than in the Pliocene strata as subdivided in this report. Some specimens of Globigerina pachyderma show sinistral coiling in samples from the up ver part of the undifferentiated Pliocene and Pleistocene. However, dextral coiling dominates in the Middleton Islend section.

Faunas from the Pliocene, or lower part of the undifferentiated Pliocene and Pleistocene, display a greater abundance of Epistominella pacifica, Glandulina laevigata, Pullenia salisburyi, and Uvigerina yabei than do faunas from the upper part of the undifferentiated sequence. These, and other forms, suggest slightly deeper water conditions for the lower part than for the upper part of the Pliocene and Pleistocinne sequence. In contrast, the dominance of elphidiids, especially Elphidium clavatum and E. bartletti, and the presence of several species of Cassidulina, suggest shallow (middle to inner shelf) and cool water conditions, particularly in the Pleistocene or upper part of the undifferentiated Pliocene and Pleistocene sequence.

\section{FAUNAL CHARACTERISTICS OF STRATIGRAPHI? SECTIONS AND WELLS}

Stratigraphic sections and wells in the Gulf of Alaska "ertiary Province have been assigned a number from 1 to 30 , and are located on the accompanying index maps. On the charts, measured sections are depicted with standard lithologic symbols and descriptions, and wells are depicted with $e^{\prime}$ 'rctric logs (spontaneous potential curves on the left, resisti rity on the right). The same numbers are used in the following discussions of individual sections and wells and to ider tify faunal checklists. There is no foraminiferal information for two sections - (28) Topsy Creek and (30) Icy Point.

\section{(1) MIDDLETON ISLAND SECTION}

Foraminifers from 16 samples collected throughout the Middleton Island stratigraphic section show no major differences in faunal composition. Furthermore, no specific taron appears useful for correlation. However, as pointed out by Ruth Todd (written commun., 1971), a change in fossil preservation occurs near the base of the section between samples 7573 and 7574. Specimens from the upper part of the section are usually well preserved and relatively undeformed, whereas in the lower part of the section they are discolored (generally an amber color), sometimes deformed, and display fewer morphologic details. The foraminiferal data indicate that the Middleton Island section is Pliocene and Pleistocene in 
age and paleomagnetic data indicate that it is probably large. ly Pleistocene (Plafker and Addicott, 1976).

Dextral coiling dominates Globigerina pachyderma throughout the section, which suggests relatively warm water. However, cold water is indicated more reliably by the consistent and sometimes common occurrence of such cold-water forms as Elphidium clavatum, Elphidium bartletti, and Buccella frigida. Such assemblages indicate shelf water depths, possibly no greater than 150 meters. Molluscan data substantiate cool to cold water and shelf depths throughout the section (Plafker and Addicott, 1976; Addicott, unpub. data 1978)

(2) MIDDLETON ISLAND STATE *1 WELL.

The faunal data available to us for this well are very meager to a depth of approximately 2,050 feet. The few foraminifers above this depth are known to occur in the Pliocene and Pleistocene of the Middleton Island section as well as in other sections of similar age in the Gulf of Alaska. Below this depth to approximately 3,050 feet, many species occur that are unknown in the Pliocene and Pleistocene (see checklist). These species collectively are indicative of an early to middle Miocene age and can best be referred to the Saucesian and Relizian Stages of the west coast of the conterminous United States.

Foraminifers that have their highest occurrence between 3,050 feet and 8,575 feet are broadly indicative of an undifferentiated Refugian and Zemorrian age. The precise age of the upper part of this sequence is somewhat uncertain because a few typical Refugian forms, such as Cassidulina cf. $C$. galvinensis, Globocassidulina globosa, and Uvigerina cf. $C$. cocoaensis, occur together with a greater number of Zemorrian species. However, assemblages from the lower part are characteristic of the Refugian Stage.

The interval between 8,575 feet and approximately 10,560 feet is characterized by the highest occurrence of species typifying the Narizian Stage (see checklist).

Samples from 10,560 to 12,002 feet, the total depth (TD) of this well, contain a distinctive fauna, one which we consider to be no younger than Ulatisian. However a considerable range of unpublished opinion exists among workers on the maximum age limit of these foraminifers. Although there are numerous uncertainties regarding identification of species in the available material from this interval, it is likely that they are no older than the Penutian Stage.

Very little paleoecologic data are available from the sparse fauna of the Pliocene and Pleistocene part of this well. However, faunas of the lower and middle Miocene part of the well differ markedly from those of the Pliocene and Pleistocene part of the Middleton Island section. As a group the Miocene assemblages suggest substantially greater water depth than do the Pliocene and Pleistocene assemblages, most likely not less than upper bathyal depths. Significant species that persist throughout this interval are Epistominella pacifica, Bulimina cf. B. inflata alligata, Uvigerinella californica, and several species of Cassidulina. Both Melonis pompilioides and Gyroidina soldanii are present locally. The fauna from the undifferentiated Refugian and Zemorrian sequence suggests little difference in water depth from that of the Miocene assemblages. Depths were probably no shallower than upper bathyal and possibly could have been as deep as middle bathyal. Significant species are Uvigerina of. $U$. cocoaensis, Sphaeroidina variabilis, Uvigerina garzaensis, Anomalina californiensis, and several species of Cassidulina. Although abundant paleoecologic data are lacking in the Narizian sequence of this well, the presence of Asterigerina crassaformis, Discorbis, and Cibicides spiropunctatus, along with several other minor occurrences of shallow-water foraminifers, indicates that water depths were probably shallower than during Refugian and Zemorrian deposition, porsibly sublittoral (neritic). The occurrence of several deep-water taxa in the lower 1,500 feet of this well, including se'reral species of arenaceous foraminifers and two species of $P$ illenia, suggests bathyal depths during middle Eocene deporition.

(3) DON MILLER HILLS SECTION

Useful foraminiferal data are limited to a meager assemblage from near the top of the section. The occurrence of both Virgulina sp. and Nonionella mioceniza suggest a tentative correlation to the upper Miocene and $\mathrm{Pl}$ xene sequence of other sections where these foraminifers occur together.

\section{(4) WINGHAM ISLAND SECTION}

Several assemblages from the upper part of this section are best referred to the lower and middle Miocene Saucesian Stage. The presence of Rotalia cf. $R$. becki, Nonionella miocenica, Valuulineria araucana, and Bulimina inflata alligata collectively are supporting criteria for a Saucesian age.

The Refugian Stage is recognized in the middle part of the section. Eponides mexicanus, Gaudryina cf. G. alazanensis, Gyroidina orbicularis planata, and Cibicides hodgei are among those few forms that typify the stag?

At least one, and possibly two, assemhlages from the lower part of the Wingham Island section t.pify the Upper Eocene Narizian Stage. Cibicides haydoni and possibly Cibicides natlandi occur in the section and are important indicators of the stage.

\section{(5) CAPE ST. PETER SECTION}

Lower and middle Miocene Saucesian foraminifers have been reported from the upper part of this se-tion by paleontologists in the petroleum industry. Our assenblages from the middle part of the section lack distinctive Saucesian character and are generally more typical of the Oligorene Zemorrian Stage. The upper Eocene Refugian Stage is well represented in the lower part of the section. Among key species occurring together in a number of assemblages from this part of the section are Uvigerina atwilli, Cibicides elmaensis, Plectofrondicularia packardi packardi, Uvigerina cf. U. gallowayi, Gyroidina condoni, and Valvulineria tumej'onsis.

Paleoecologic evidence from all assemb' ${ }^{\prime}$ ges of this section indicates deep and cold water. Significent environmental indicators are costate buliminids and uvigerinids, Plectofrondicularia packardi packardi, Melonis pompilioites, Valuulineria tumeyensis, and several species of Gyroidina and Globocassidulina. (6) KAYAK ISLAND WEST SECTION AND (7) KAYA K ISLAND NORTH
SECTION

The uppermost assemblage from the Kayak Island west section is clearly referable to the lower and middle Miocene Saucesian Stage, mainly on the basis of the joint occurrence of Siphogenerina kleinpelli and Uvigerinella obesa impolita. Two additional assemblages, widely spaced stratigraphically below the top of the section, are questionably referred to the Saucesian Stage; because diagnostic species are absent, these assemblages could be referred alternatively to the Zemorrian Stage.

The lower part of the Kayak Island north section is referred to the upper Eocene Refugian Stage. Alt 'ough a number of the species present are known to occur in both the Refugian and Narizian Stages in the conterminous United States, the sporadic occurrence throughout the section of Refugian species such as Uvigerina cocoaensis, Sigmomorphina pseudoschencki, and Plectofrondicularia packardi packardi favors a Refugian age. 
Because deep, cold-water species occur in all assemblages, the entire section was most likely deposited under bathyal conditions. Siphogenerina and hispid and costate uvigerinids in the upper part of the section and such taxa as Plectofrondicularia packardi packardi, Melonis pompilioides, several species of Gyroidina, and costate uvigerinids in the lower part all substantiate bathyal conditions

(8) KAYAK ISLAND EAST SECTION AND (9) CREEK "E” AND REEF SECTION

Two assemblages from widely spaced localities of the Kayak Island east section and several from the upper part of the Creek "E" and Reef section all firmly suggest a Saucesian age. The mutual occurrence of Siphogenerina kleinpelli and Uvigerinella obesa impolita in many of these assemblages supports this conclusion. One assemblage from the Creek " $E$ " and Reef section is questionably referred to the Zemorrian Stage, mainly on the basis of the presence of Anomalina californiensis and Cibicides cf. C. elmaensis var. A; diagnostic Saucesian and Refugian forms are missing. The Refugian Stage is well represented by a number of assemblages containing such significant species as Cibicides hodgei, Bulimina schencki, Bulimina sculptilis laciniata, Plectofrondicularia packardi packardi, Uvigerina atwilli, and Uvigerina cocoaensis. The base of the section is referred to the upper Eocene Narizian Stage largely on the basis of the occurrence of Cibicides natlandi in one assemblage.

Bathyal depths are indicated clearly by the foraminifers occurring throughout most of both sections. Upper bathyal depths may have existed during most of the Saucesian deposition as suggested by the mutual occurrence of Siphogenerina kleinpelli, Uvigerinella obesa impolita, and Bolivina marginata adelaidana. Middle or upper bathyal depths most likely existed during Zemorrian and Refugian deposition as suggested by the combined occurrences of deep water and intermediate depth foraminifers such as costate uvigerinids and buliminids, Plectofrondicularia packardi packardi, Bulimina schencki, and Globocassidulina. Shallower conditions, possibly sublittoral (neritic), may have existed during Narizian time because no demonstrably deep-water species occur in the Narizian assemblages. Furthermore, several taxa, particularly Cibicides natlandi and quinqueloculinids, are present that probably lived in shallow water.

\section{(10) SUCKLING HILLS SECTION}

None of the eleven assemblages from localities in this section is diagnostic of a precise age. However, the combination of Pliocene and Pleistocene species such as Elphidium clavatum, Globigerina pachyderma, Buccella frigida, and Cassidulina californica together with species known from the lower and middle Miocene sequence such as Nonionella miocenica, Uvigerina peregrina, Sphaeroidina sp., and Cibicides cf. C. pseudoungerianus evolutus suggests an intermediate stratigraphic position that is referred to as undifferentiated upper Miocene and Pliocene. A few foraminifers characteristically occur in this and other sections that are referred to the undifferentiated upper Miocene and Pliocene, namely Melonis zaandamae, Florilus labradoricus, and Virgulina sp.

In assemblages from the upper part of the section, cool to cold water shelf conditions are indicated by the occurrence of Elphidium clavatum, a dominance of sinistrally coiled Globigerina pachyderma, and by the presence of several species of Cassidulina. Costate uvigerinids and Epistominella pacifica in the lower part of the section indicate deeper water conditions, perhaps upper bathyal depths.
(11) KULTHIETH MOUNTAIN SECTION

Much of the upper part of this section is broadly referred to the undifferentiated Pliocene and Pleistocene, on the basis of eight assemblages from widely spaced localities. Further refinement does not appear warranted on the basis of the available materials. About 1,500 feet of the lower part of the section is referred to the undifferentiated upper Miocene and Pliocene. Both Anomalina cf. A. glabrata and Melonis zarndamae occur here, and, although their presence does not necessarily connote a precise age, they are not known to occur above our locally designated undifferentiated upser Miocene and Pliocene. These forms together with a number of species common to the Pliocene and Pleistocene seque nce apparently indicate an age no older than late Miocene.

Cold water shelf conditions are suggested by mos ${ }^{\wedge}$ of these assemblages. Elphidium clavatum, Elphidium $\mathrm{cf}$. E. bartletti, Cassidulina tortuosa, Epistominella pacifica, and several arenaceous species collectively indicate cold water sublittoral conditions. Slightly deeper upper slope depths may have existed during the deposition of the lower part of the section, as indicated by the presence of Uvigerina cf. $U$. jun :ea and Melonis zaandamae.

\section{(12) DUKTOTH RIVER \#1 WELL}

No faunal data were available to a depth of 1,400 feet. From 1,400 to 2,700 feet very sparse data indicate an age possibly no younger than the Zemorrian Stage. Stratigraphirally lower assemblages to a total depth of 10,360 feet sugcest a Refugian age. Species present that are particularly indicative of the Refugian are Cibicides hodgei, Bulimina sculpt lis, Uvigerina cocoaensis, Uvigerina atwilli, Valvulineria willapasnsis, Sigmomorphina schencki, and Bulimina schencki.

Water depths during Refugian deposition were most lirely in the upper bathyal range. This range is evidenced by the collective presence of bathyal foraminifers such as large costate uvigerinids and buliminids, robust species of Eponides, and possibly Valuulineria willapaensis in combination with a few shallower or intermediate depth foraminifers such as large quinqueloculinids, and species of Elphidium and Pseudoglan. dulina. These intermediate depth foraminifers may also indicate relatively warm water for such depths.

\section{(13) YAKATAGA REEF SECTION}

Faunas from nine localities throughout much of the Yakataga Reef section can be divided generally into two age groups. Those faunas from the upper five and possibly six localities contain a number of species that locally typify the undifferentiated upper Miocene and Pliocene sequenre. Elphidium clavatum, Cibicides cf. C. mckannai, Anomalina cf. A. glabrata, Virgulina sp., and Cassidulina cf. E. islandica in aggregate occur only in those assemblages that we have assigned to the undifferentiated upper Miocene and Pliocene, although some species are known to occur higher and others lower in local sections.

Faunas from the lower three localities of the section are referred to the Oligocene Zemorrian Stage although they are not easily differentiated from faunas of the lower and midfle Miocene Saucesian Stage. The presence of Melonis pcmpilioides, Gyroidina soldanii, Sphaeroidina variabilis, Cibicites cf. C. pseudoungerianus evolutus, and Bulimina inflata alligata, which are not commonly known above the Saucesian Stage locally, distinguish this part of the section from the undifferentiated upper Miocene and Pliocene. Futhermcre, the presence of Sigmomorphina pseudoschencki, a speries that has not been recorded above the Zemorrian Stage, s' $\mathrm{g}$ gests that this lower part of the Yakataga Reef section may be Zemorrian. 
Assemblages from the upper part of the section suggest cool to cold water temperatures at sublittoral depths. Shallower depths probably existed during the deposition of the uppermost part of the section as indicated by the greatest abundance there of Elphidium clavatum as well as quinqueloculinids. Greater water depths are indicated by the assemblages of the lower part of the section where foraminifers appear that characterize bathyal depths-Melonis pompilioides, Gyroidina soldanii, Sphaeroidina variabilis, and Bulimina inflata alligata. The combined foraminiferal fauna of this lower part of the section indicates that deposition took place in cold water at depths no shallower than upper bathyal.

\section{(14) WHITE RIVER *3 WELL}

Faunas from approximately the upper 500 feet of the well are not particularly diagnostic of age, but several species, Melonis cf. M. zaandamae, Anomalina cf. A. glabrata, and possibly Cassidulina of. $C$. islandica occur consistently in those parts of other sections and wells that are broadly referred to the undifferentiated upper Miocene and Pliocene. The first two of these species have not been recorded above this interval, and therefore the containing beds are not likely to be younger than our undifferentiated upper Miocene and Pliocene interval. Almost no data are available for the interval from 500 feet to a depth of about 1,200 feet where Saucesian siphogenerinids first appear. Saucesian foraminifers continue to appear to depths of at least 3,000 feet, but a few Zemorrian foraminifers also appear. Because assemblages are from well cuttings, the top of the Zemorrian Stage could be in the interval 1,200-3,000 feet even though it is shown questionably below this interval on the chart. No appreciable data were available from a depth of approximately 3,000 feet to the total depth of 6,982 feet.

Foraminifers from the upper 500 feet of this well indicate temperate to cool water shelf conditions. Species of Quinqueloculina, Florilus, and Elphidium, together with several species of cassidulinids, are among those forms supporting this conclusion. In contrast, foraminifers from the lower part of this well indicate bathyal conditions - particularly by species of Siphogenerina associated with costate buliminids, uvigerinids, and species of Epistominella.

\section{(15) WHITE RIVER *2 WELL}

The sparse fauna from the upper 1,200 feet of this well broadly suggests a correlation with our undifferentiated Pliocene and Pleistocene interval. Elphidium clavatum and Elphidiella oregonensis are among species that characterize the foraminiferal fauna of this interval. No data are available from 1,200 feet to 1,600 feet. Although none of the assemblages from approximately 1,600 feet to 3,600 feet is particularly diagnostic of age, the occurrence of several species, particularly Melonis of. M. zaandamae and Anomalina cf. A. glabrata in the lower part, suggests assignment to the undifferentiated upper Miocene and Pliocene. The lower to middle Miocene Saucesian Stage is marked by the highest occurrence in this well at approximately 3,600 feet of Siphogenerina kleinpelli, Bulimina inflata alligata, Bolivina marginata adelaidana, and several other Saucesian species. Although the top of the Zemorrian Stage is not precisely defined by available data, the stage is generally suggested in assemblages from the interval between approximately 4,100 feet and 5,000 feet. Karreriella sp., Cassidulina crassipunctata, and Florilus cf. F. incisum are among characteristic Zemorrian foraminifers occurring in this interval. The top of the Refugian Stage is suggested by the highest occurrence of Eponides mexicanus and Cibicides elmaensis at about 5,200 feet. The possible occurrence of Valvulineria tumeyensis at
5,500 feet to 5,600 feet further substantiates a Refugian age The available data below a depth of about 6,000 feet are insignificant and probably largely represent cavings from higher in the well.

Relatively cool to cold water conditiors at sublittoral depths most likely persisted during the deposition of the Pliocene and Pleistocene, as evidenced by such species as Elphidium clavatum and Elphidium bartlett together with Elphidiella oregonensis and other cold or shallow water species. Deeper water conditions at possibly onter shelf to upper bathyal depths probably existed, at least at times, during upper Miocene and Pliocene deposition. Melonis pompilioides and several species of costate uvigerinic's are among foraminifers suggesting greater water depths. Bathyal depths also are suggested by the Saucesian and Zemorrian assemblages of this well. Diagnostic deep-water taxa are siphogenerinids, Sphaeroidina sp., Bolivina marginata adelaidana, and Gyroidina soldanii.

(16) SULLIVAN \#1 WELL

Pliocene and Pleistocene species such as Elphidium clavatum, Cassidulina californica, and Q.inqueloculina akneriana occur in approximately the upper 300 feet of this well. Uvigerinella obesa impolita and Nonior.olla miocenica occur between approximately 300 and 400 fret and suggest a Saucesian age. Typical Zemorrian assembla.tes first appear at about 400 feet and continue to occur to t least a depth of 3,700 feet. Among characteristic Zemorrian species are Buccella mansfieldi oregonensis, Sicmomorphina pseudoschencki, Florilus incisum, Cibicides elmaensis, and Gaudryina alazanensis. The top of the Refug: $2 n$ Stage is indicated at about 3,800 feet by the highest occurrence of both Valvulineria willapaensis and Melonis halkyardi. Additional species that characterize the Refugian Stage continue to make appearances nearly to the bottom of this well at 10,013 feet. Among these species are Elphidium cf. E. californicum, Sigmomorphina of. S. schencki, Uvigerira cocoaensis, Cassidulina galvinensis, and Cibicides hodgei.

Pliocene and Pleistocene assemblages generally suggest shelf depths and possibly cool to cold water. Deeper, coldwater environments, possibly in the middle to upper bathyal range, are suggested by both Zemorrian and Refugian assemblages. Gyroidina soldanii, Gaudryira alazanensis, Uvigerina cocoaensis, and Cassidulina crassipunctata are among those species thought to favor substantial depths. Elphidium cf. E. minutum in a few Zemorricn assemblages and Elphidium cf. E. californicum in s?me Refugian assemblages may indicate short periods of slightly shallower conditions.

\section{(17) SULLIVAN \#2 WELL}

Assemblages from the upper 300 feet of this well are tentatively referred to our undifferentiated upper Miocene and Pliocene sequence largely because Anomalina cf. A. glabrata, a species recorded lower but rarely higher than this interval, occurs here with higher ranging forms sucl as Elphidium clavatum, Florilus labradoricus, Elphidium bartletti, and Buccella frigida. A distinct faunal break occurs at a depth of about 300 feet where, for the most part, Zemorrian species first occur. All or part of the interval between 300 an -400 feet may be Saucesian in age on the basis of the questionable identification of Siphogenerina cf. S. transuersa. Other assemblages from this interval are better referred to the Zenorrian Stage, and therefore this small interval is tentatively r?garded as part of the Zemorrian Stage. Occurring between about 300 and 1,300 feet are species typically associated uith the Zemorrian Stage. Among these are Gyroidina soldarii, Pseudoglan- 
dulina aff. $P$. inflata, Valvulineria menloensis, Gaudryina alazanensis, Cassidulina crassipunctata, Cibicides elmaensis, and Anomalina californiensis.

Faulting is indicated by anomalous faunal sequences in several intervals in this well. The occurrence of Cassidulina galvinensis and questionable occurrence of Vaginulinopsis saundersi in an interval between 1,300 and 1,500 feet suggests a Refugian age. However, beginning at about 1,500 feet and continuing to possibly 2,000 feet additional Zemorrian species occur; thus a block of Refugian (at 1,300-1,500 feet) may be faulted into an otherwise continuous sequence of Zemomian strata. Refugian species once again appear at about 2,100 feet and continue to dominate the assemblages to a depth of some 8,000 feet. Elphidium californicum, Valvulineria willapaensis, Uvigerina cocoaensis, Cibicides hodgei, and Sigmomorphina cf. S. schencki are among the diagnostic species appearing in this interval.

Although the evidence is not conclusive, Zemorrian beds may again be present between approximately 8,800 and 9,600 feet. No additional Zemorrian species appear here, but several that occurred higher in the well reappear. These occurrences, of course, could also be the result of contamination from higher in the well.

A distinct faunal break occurs at 9,900 feet where younger beds are indicated by the presence of Saucesian species such as Siphogenerina cf. $S$. transuersa and Uvigerinella obesa impolita. These and (or) other characteristic Saucesian species continue to the bottom at 12,054 feet.

The upper Miocene and Pliocene faunas suggest a cold water, outer shelf environment. Substantiating evidence is the combination of several species of cold water Elphidium, Buccella frigida, and Cassidulina islandica together with deeper water foraminifers such as Epistominella pacifica. Saucesian assemblages distinctly indicate bathyal conditions, possibly as deep as middle bathyal, as substantiated by the presence of Siphogenerina and Bolivina marginata adelaidana together with costate buliminids and uvigerinids. Both Zemorrian and Refugian assemblages also suggest bathyal depths, however, the presence of species of both Elphidium and Quinqueloculina in each assemblage together with typical bathyal foraminifers such as Gyroidina soldanii, Melonis pompilioides, and Uvigerina cocoaensis, indicates that depths were probably no greater than upper bathyal.

(18) RIOU BAY \#1 WELL

Approximately 500 assemblages from small intervals throughout this well were examined in detail. A summary of the faunal distribution is presented in the checklist. Data from small intervals were combined into larger depth intervals where no significant faunal change was observed.

The upper part of this well to a depth of approximately 6,400 feet is referred to the Pleistocene; strata in the lower part of the well between approximately 8,400 and 14,107 feet, the total depth of the well, are questionably referred to the Pliocene. The age boundary occurs somewhere within about 2,000 feet of section where faunal data is insufficient to distinguish between Pliocene and Pleistocene. Among the differences in the faunas of these subdivisions is the dominance of dextrally coiled Globigerina pachyderma in the lower part, suggesting warm conditions. Furthermore, fossils from the lower part of the well are less well preserved than those from the upper part. In addition, Uvigerina cf. $U$. yabei is restricted to the lower part of this well. This species, although not restricted to the Pliocene, is more common in the lower part of the Pliocene and Pleistocene sequence of the Gulf of Alaska. Furthermore, Elphidiella nitida and Elphidium frigidum, which are confined to the upper part of the well, characterize the Pleistocene part of the local sequence. Other faunal occurrences that may be useful for local correlation are the highest occurrence of both Cassidulina californi:a and Elphidiella oregonensis at approximately 2,100 feet. F whaps a more practical reference horizon is the highest common occurrence of Elphidiella oregonensis at approximately 2,860 feet. The lower occurrrence of Elphidiella nitida at abou' 6,500 feet may also be useful for local correlation. This horiz on corresponds closely to a change in fossil preservation. Most of these marker horizons have been note in some of th? other sections and wells of the Malaspina and Yakutat Districts, and they generally occupy the same relative positions in the sequence (see correlation charts).

The abundance and diversity of elphidiids through out this thick sequence of Pliocene and Pleistocene rocks indicate that sublittoral water depths prevailed during deposition. The greatest depths are suggested in the lower (Pliocene?) part of the section where, in addition to shallow-water forms, Uvigerina cf. $U$. yabei and Epistominella pacifica occir consistently. Collectively, these species indicate that water depths were perhaps outer sublittoral (outer shelf).

Water temperatures were most likely relatively cool or cold during the deposition of at least the upper (Pleistocene) part of this section because, for the most part, the elfhidiids such as Elphidium clavatum and Elphidiella groen'andica together with Buccella frigida and other cold-water foraminifers appear consistently through this part of this section. Some of these taxa are not present, at least not consistently, in th? lower (Pliocene?) part of the well but others, such as Elphidium clavatum, continue to be common consistently. Dextrally coiled Globigerina pachyderma supports evidence for re'atively warm water conditions. In view of somewhat corflicting evidence for water temperature in the lower part of th is well, it would seem that surface temperatures, as represented by the planktonic foraminifers, may have been relatively warm but, because of the greater depths of deposition, bottom temperatures were relatively cool to cold.

\section{(19) CHAIX HILLS SECTION}

Two assemblages, one from near the top of the section and one from the base, are referred to the undifferentiated Pliocene and Pleistocene on the basis of the common occurrence in the lower assemblage of both Elphidium clavatum and Pseudononion auricula together with a few Euccella frigida, Cassidulina islandica, and Elphidiella oregonensis. Elphidium clauatum, present in both assemblages, s' cold, shallow water conditions of deposition. This species in the basal assemblage, together with Buccella frigida, Cassidulina islandica, Elphidium oregonensis, and Quinqueloculina akneriana, collectively support cool to colit water conditions at sublittoral (shelf) depths.

\section{(20) SAMOVAR HILLS SECTION}

Three sparse assemblages from widely spaced intervals of the upper half of this measured section are broadl. ' referred to the undifferentiated Pliocene and Pleistocene senuence. Elphidium clavatum and $E$. bartletti together with Florilus labradoricus and Uvigerina yabei locally characterize beds of the undifferentiated Plicoene and Pleistocene sequence.

Cool water and sublittoral depths are suggested by Elphidium clavatum and E. bartletti together with Erıccella frigida. Uvigerina yabei in the lowest assemblage is suggestive of the greater water depth.

\section{(21) MALASPINA \#1A WELL}

Studies of this well are based largely on assemblages from about 150 intervals between depths of 120 and 8,000 feet. 
A summary of the faunal content of this part of the well is presented in the checklist. Data from small intervals were combined into larger intervals where no significant change in the fauna was observed. The entire sequence is broadly referred to the Pliocene and Pleistocene undifferentiated.

Sinistral coiling of Globigerina pachyderma dominates in the upper part of this well, suggesting cold water conditions, as would be expected in a Pleistocene sequence. A change in fossil preservation was noted at approximately 5,600 feet, similar to that observed in the Riou Bay well at about 6,400 feet, a position corresponding generally to the base of the Pleistocene as interpreted in that well. In addition, the highest occurrence of Cassidulina californica at 2,100 feet, Elphidiella oregonensis at $4,100 \mathrm{feet}$, and the common occurrence of this species near 5,600 feet, may represent significant horizons for at least local correlations. It is noteworthy that these events occur in the same sequence in the Riou Bay well. Furthermore, for the most part they continue to occur in the same sequence in wells of the Yakutat area to the southeast. No significant faunal data were available from this well below 8,000 feet.

The foraminifers from the undifferentiated Pliocene and Pleistocene sequence suggest cool to cold water at sublittoral depths, possibly no greater than a depth of 60 meters. This interpretation is based on the consistent and relatively common occurrence of Elphidium clavatum, the scattered occurrence of Elphidium bartletti, and the consistent occurrence of Cassidulina islandica, and Elphidiella groenlandica throughout this interval. In addition, the sinistral coiling of Globigerina pachyderma further supports cold water conditions in the upper half of this sequence, while the presence of Elphidiella oregonensis in only the lower part of the sequence may indicate slightly warmer water.

\section{(22) YAKUTAT *1 WELL}

Faunas from the interval betweeen 600 and 4,900 feet are broadly referred to the undifferentiated Pliocene and Pleistocene. Within this interval the highest occurrence of Elphidiella oregonensis at a depth of about 1,200 feet and its common occurrence between depths of 3,300 feet and 3,500 feet are elements potentially useful for at least local correlations. Inoceramus prisms are reported as high as 4,900 feet and occur sporadically in the records to nearly the total depth of 9,314 feet. These are believed to be reworked into younger rocks at least throughout much of this interval because Eocene foraminifers appear at a depth of about 5,400 feet and continue to appear nearly to the total depth. Late Eocene foraminifers referable to the Narizian Stage appear between depths of 5,900 feet and 6,800 feet. Between 6,800 feet and the total depth $(9,314$ feet) only scattered occurrences of a few Eocene species are reported, and many intervals are barren of faunal data. This large interval, therefore, is tentatively regarded as undifferentiated Ulatisian and Narizian in age.

Shallow, depths and cool to cold water conditions throughout deposition of the Pliocene and Pleistocene sequence are evidenced by the consistent and frequently common occurrence of Elphidium clavatum and Elphidiella nitida, together with scattered occurrences of Buccella frigida. Cassidulina islandica and Elphidium bartletti also indicate cold water conditions largely in the upper part of this sequence whereas the scattered and sometimes common occurrence of Elphidiella oregonensis and the sparse occurrence of Buliminella elegantissima in the lower part provide supporting evidence for slightly warmer conditions.

The Eocene foraminifers as a whole suggest fairly deep water conditions. Smooth buliminids, several species of Eponides and Cibicides, together with many of the remain- ing foraminifers, most likely would have thrivec' in an outer shelf or upper bathyal environment.

\section{(23) YAKUTAT *3 WELL}

The upper 2,600 feet of this well is referred to the undifferentiated Pliocene and Pleistocene. Although the available data are somewhat generalized throughout parts of this interval, several possible horizons of correlation are suggested. The highest occurrence of Cassidulina californica $\mathrm{a}^{+} \mathrm{a}$ depth of about 450 feet corresponds to the highest occurrence of this taxon in the upper part of several other wells $t>$ the north. Elphidiella nitida occurs commonly between derths of about 900 feet and 1,400 feet. This species occurs ir the nearby Yakutat \#2 well at a similar relative position. Elphidiella oregonensis is common in the interval between depths of 2,340 feet and 2,430 feet. This relative position also corresponds to the common occurrence of this speciss in several wells to the north. Between depths of about 2,600 feet and 3,250 feet almost no foraminiferal data have been recorded. However, the first and common occurrence of glauconite at a depth of about 2,950 feet corresponds to a similar stratigraphic occurrence in the nearby Yakutat 11 well. The occurrence of Bulimina of. B. schencki at about 3,250 feet marks the highest occurrence of Eocene foraminifers in this well. The relative position of this occurrence corresponds to that in the nearby Yakutat $\# 1$ well. Eocene foraminifers referable to the Narizian Stage continue to occur sporadically to a depth of some 7,300 feet. Inoceramus prisms together with characteristic Cretaceous foraminifers make their highest occurrence at a depth of about 7,600 feet. Late. Cretaceous species are recorded to a depth of 9,400 feet and Early Cretaceous species are recorded from a core taken between depths of 10,446 feet and 10,456 feet (W. V. Sliter, written commun., 1977).

Pliocene and Pleistocene faunas of this well indicate much the same paleoecologic conditions of cool to cold water at shelf depths as are indicated locally in other F'iocene and Pleistocene sequences. Eocene assemblages siaggest outer shelf to upper bathyal conditions. Smooth buliminids, Gyroidina orbicularis planata, Plectofrondicularia and several species of Anomalina are among those foraminifers indicative of such conditions. Shelf conditions are indicatef by most of the Cretaceous elements particularly such taxa as Choffatella and Orbitolina, together with fragments of bryozoans, echinoids, and Baculites (W. V. Sliter, written commun., 1977).

\section{(24) YAKUTAT *2 (A-1) WELL}

Foraminifers reported from approximatel, the upper 2,500 feet of this well are representative of the local undifferentiated Pliocene and Pleistocene sequence. The highest occurrence of Cassidulina californica at a depth of approximately 950 feet and the common occurrence of Elphidiella nitida between depths of approximately 1,000 fe?t and 1,200 feet are noted as possible points of local correlation. These species are present at similar relative stratigraphic positions in the nearby Yakutat \#3 well, and Cassidulina californica makes its highest occurrence in the upper part of a number of other wells to the northwest. No data are available for the depth interval from approximately 2,500 to 3,200 feet. Inoceramus prisms are reported to first occur at about 3,200 feet and continue throughout most of the lower part of the well. Other Cretaceous taxa, all regarded as Lat? Cretaceous (W. V. Sliter, written commun., 1977), are not re sorted above 10,000 feet. Evidence for a Cretaceous age for the depth interval from 3,200 and 10,000 feet is the appearance of Inoceramus prisms and a major lithologic change at about 3,200 feet. 
Typical cool to cold water shelf conditions are suggested by the faunas of the undifferentiated Pliocene and Pleistocene sequence. Elphidium clavatum occurs less frequently and in fewer numbers in this well than it does in wells and sections to the north and west. Perhaps this is evidence for slightly warmer water conditions, particularly when considered with the occurrence of Buliminella elegantissima and Cibicides mckannai. The first occurrence of Epistominella pacifica in the lower 1,200 feet or so of the undifferentiated Pliocene and Pleistocene interval suggests that water depths were probably greater during the deposition of the lower part of the sequence (possibly middle shelf). The dominance of a variety of arenaceous foraminifers in Cretaceous assemblages is evidence for cold water, outer shelf to upper slope conditions.

\section{(25) DANGEROUS RIVER \#1 WELL}

Foraminiferal data on this well are from a report prepared by Ruth Todd (written commun., 1962) on 33 slides that were made from cuttings taken between depths of 3,660 feet and 8,634 feet. Because these specimens are so poorly preserv$e d$ and are largely nondiagnostic arenaceous foraminifers, they provide limited biostratigraphic information. No checklist has been prepared. Inoceramus prisms were reported in the lower part of the sequence below a depth of 5,670 feet, and Globotruncana sp. was identified from the interval between depths of 7,650 and 7,680 feet. On the basis of these data, the rocks penetrated in the lower part of the well are Creataceous in age. The top of the Cretaceous is not apparent from these data but is placed at about 1,700 feet on the basis of the well cuttings and electric logs.

\section{(26) FAIRWEATHER GLACIER SECTION}

Available foraminiferal assemblages are confined to the upper one-half or about 700 feet of this section. As a group, these faunas best compare with those of Pliocene and Pleistocene strata of the Gulf of Alaska Tertiary Province. The common and only occurrence of Elphidiella oregonensis at approximately 700 feet below the top of this section seems to be significant to local biostratigraphic correlations because this species occurs in large numbers in a similar stratigraphic position in the La Perouse Glacier section to the south and in several other sections and wells to the northwest.

Shallow cool to cold water conditions are suggested by the persistent occurence of Elphidium clavatum, together with scattered Elphidium bartletti, Buccella frigida, Nonionella miocenica, and Florilus labradoricus. In contrast, slightly greater depths are suggested by the persistent occurrence of Epistominella cf. E. pacifica and Uvigerina cf. U. yabei and by one occurrence of Pullenia salisburyi. Considering both depth indications, optimum conditions for such foraminifers most likely would have been middle shelf at depths something less than outer shelf.

\section{(27) CENOTAPH ISLAND SECTION}

The material available for study consisted of a few meager foraminiferal assemblages from the upper 700 feet of this section. The presence of Anomalina cf. A. glabrata together with Nonionella miocenica, Buccella frigida, and Pseudononion auriculata in the lower part of this interval suggests that this part of the section, at least, is best referred to the undifferentiated upper Miocene and Pliocene sequence.

Shallow, cold water conditions are suggested by the combined foraminiferal fauna.

\section{(29) LA PEROUSE GLACIER SECTION}

The entire section is referred to the Pliocene and Pleistocene. The lower part is specifically referred to the Pliocene and the upper part to the Pleistocene. However, the
Pliocene-Pleistocene transition is represented by over 2,500 feet of section designated as undifferentiated Pliocene and Pleistocene. No data are available for a large part of this interval.

In the Pleistocene part of the section Globigerina pachyderma commonly displays sinistral coiling. Furthe"more, Elphidiella nitida is confined to this part of the section, an occurence that conforms to its high stratigraphic occurrence in nearly all other undifferentiated Pliocene and Pleistocene sections studied.

In the Pliocene part of the section Epistominella Facifica and Glandulina laevigata occur consistently throughout, and Pullenia salisburyi and Virgulina nodosa have a limit od occurrence. Although all of these species may be more indicative of a difference in depositional environment than age, they nevertheless are characteristic elements of a lower (Plincene) part of the local Pliocene and Pleistocene sequence.

Several additional faunal elements are noted as possibly significant for local correlations because they occur consistently in other Pliocene and Pleistocene sections described in this report. Both Elphidiella oregonensis and Cassidulina californica make their highest occurrence in the upper part of the section. The common occurrence of Elphidiella oregcnensis slightly below its highest occurrence in this section also corresponds to a similar occurrence in other local section?. Furthermore, a distinct change in the quality of fossil preservation is noted about 5,000 feet below the top of the sizction; all assemblages below are referred to the Pliocene. This relative position generally corresponds to similar changes in preservation noted in several other sections.

Cool to cold water conditions at sublittoral depths are indicated by the common occurrence of Elphidium clavatum throughout this Pliocene and Pleistocene section. R.icella frigida, Cassidulina teretis, and Cassidulina islandica particularly are indicative of cold water. Slightly greater depths a*o suggested in the Pliocene part of the section by the corsistent occurrence of Epistominella pacifica and Glandulina laevigata together with the sporadic occurrence of Pullenia salishuryi. At times water temperature may have been slightly u'armer than during the Pleistocene deposition even though water depths may have been greater, because several spe ries of miliolids appear in this part of the section together witt a few dextrally coiled Globigerina pachyderma.

\section{REFERENCES}

References marked with an asterisk (") are thos? cited in the text. Uncited references served as important general sources of information on foraminifers, particularly cn taxonomic and paleoecologic affinities.

-Addicott, W. O., Winkler, G. R., and Plafker, George, 1978, Preliminary megafossil biostratigraphy and correlation of selected stratigraphic sections in the Gulf of Alaska Tertiary Province: U.S. Geological Survey Open-File Foport 78-491, 2 pls.

Armentrout, J.M., 1981, Correlation and ages of Cenozoic chronostratigraphic units in Oregon and Washington: Geological Society of America Special Paper 184, p. 137-148.

Arnal, R. E., and Vedder, J. G., 1976, Late M-ocene paleobathymetry of the Califomia continental bord orland north of $32^{\circ}$ in Fritsche, A. E., and others, eds., Neogene symposium; selected technical papers: American Association of Petroleum Geologists, Society of Economic Paleontologists and Mineralogists, Pacific Section. 1976 Annual Meeting, San Francisco, California, p. 1-8. 
Bandy, O. L., 1960, The geologic significance of coiling ratios in the foraminifer Globigerina pachyderma (Ehrenberg): Journal of Paleontology, v. 34, no. 4, p. 671-681, 7 figures.

1967, Foraminiferal definition of the boundaries of the Pleistocene in southern California, U.S.A., in Progress in oceanography, v. 4: Oxford and New York, Pergamon Press, p. 27-49.

Bandy, O. L., and Arnal, R. E., 1957, Some new Tertiary and recent foraminifera from California and the eastern Pacific Ocean: Cushman Foundation for Foraminifera Research Contributions, v. 8., part 2, p. 54-58, plates $6,7$.

Boltovskoy, Esteban, and Wright, Ramil, 1976, Recent Foraminifera: The Hague, Netherlands, Dr. W. Junk, v. $\mathrm{V}, 515 \mathrm{p}$.

- Cooper, S. C., 1964, Benthonic Foraminifera of the Chubkchi Sea: Cushman Foundation for Foraminifera Research Contributions, v. 15, part 3, p. 79-104.

-Cushman, J. A., 1941, Some fossil Foraminifera from Alaska: Cushman Foundation for Foraminifera Research Contributions, v. 17, part 2, p. 33-38, plates 9, 10. 1947, A foraminiferal fauna from Amchitka Island, Alaska: Cushman Foundation for Foraminifera Research Contributions, v. 23, part 3, p. 60-72, plates 13-16.

Cushman, J. A., and Gray, H. B., 1946, A Foraminiferal fauna from the Pliocene of Timms Point, California: Cushman Laboratory for Foraminifera Research Special Publications no. 19,46 p., 8 plates.

-Cushman, J. A., and Todd, Ruth, 1947, Foraminifera from the coast of Washington: Cushman Foundation for Foraminiferal Research Special Publications no. 21, 23 p., 4 plates.

Donnelly, A. T., 1976, The Refugian Stage of the Californa Tertiary: foraminiferal zonation, geologic history, and correlations with the Pacific Northwest: Santa Barbara, University of California, Ph.D. thesis, $316 \mathrm{p}$

Enbysk, B. J., 1960, Distribution of Foraminifera in the northeast Pacific: Seattle, University of Washington, $\mathrm{Ph} . \mathrm{D}$. thesis, 150 p., 21 plates, appendix.

Galloway, J. J., and Wissler, S. G., 1927, Pleistocene Foraminifera from the Lomita quarry, Palos Verdes Hills, California: Journal of Paleontology, v. 1, no. 1, p. 35-87, plates 7-12.

Ingle, J. C., 1972a, Biostratigraphy and paleoecology of early Miocene through Pleistocene benthonic and planktonic Foraminifera, San Joaquin Hills, Newport Bay, Orange County, California, in Proceedings of the Pacific Coast Miocene biostratigraphic symposium: Society of Economic Paleontologists and Mineralogists, Pacific Section, 1972 Annual Meeting, Bakersfield, California, p. 255-283.

$1972 \mathrm{~b}$, Late Neogene paleobathymetry and paleoenvironments of the Humboldt basin, northern California, in Fritsche, A. E., and others, eds., Neogene symposium; selected technical papers: American Association of Petroleum Geologists, Society of Economic Paleontologists and Mineralogists, Pacific Section, 1976 Annual Meeting, San Francisco, California, p. 53-61.

Kleinpell, R. M., 1938, Miocene stratigraphy of California: Tulsa, American Association of Petroleum Geologists, 450 p., 22 plates.

Kleinpell, R. M., and Weaver, D. W., 1963, Oligocene biostratigraphy of the Santa Barbara embayment, California: University of California Publications in Geological Science, v. 43, 250 p.
-Loeblich, A. R., Jr., and Tappan, Helen, 195: Studies of Arctic Foraminifera: Smithsonian Miscellaneous Collection, v. 121 , no. 7,150 p., 24 plates.

1964, Treatise on invertebrate paleon ${ }^{+}$logy, Part C, Protista 2: Geological Society of American, v. 2, 900 p.

Mallory, V. S., 1959, Lower Tertiary biostratigraphy of the California Coast Ranges: Tulsa, American Association of Petroleum Geologists, 416 p., 42 plates.

Martin, Lewis, 1952, Some Pliocene Foraminiferc from a portion of the Los Angeles basin, California: Cushman Foundation for Foraminifera Research Contributions, v. 3, parts 3 and 4, p. 107-141, plates 17-25.

Natland, M. L., 1950, Report on the Pleistocene and Pliocene Foraminifera, in Anderson, C. A., and otherr. 1940, W. W. Scripps cruise to the Gulf of California: Geological Society of America Memoir 43, part 4, p. 1-55, plates $1-11$.

Nelson, S.W., Dumoulin, J.A., and Miller, M.L., 1983, Geologic map of the Chugach National Forest, Alaska: U.S. Geological Survey Miscellaneous Field Studies Map MF-1645-B.

Pierce, R. L., 1956, Upper Miocene Foraminif ra and fish from the Los Angeles area, California: Joumal of Paleontology, v. 30, no. 6, p. 1288-1314, plater 137-144.

Plafker, George, 1967, Geologic map of the Gulf of Alaska Tertiary Province, Alaska: U.S. Geological Survey Miscellaneous Geological Investigations Map I-484, scale $1: 500,000$

1971, Pacific margin Tertiary basin, in Future petroleum provinces of North America: American Association of Petroleum Geologists Memoir 15, p. 120-135

- Plafker, George, and Addicott, W. O., 1976, C'aciomarine deposits of Miocene through Holocene age in the Yakataga Formation along the Gulf of Alarka margin, Alaska, in Miller, T. P., ed., Recent and ancient sedimentary environments in Alaska: Anchorane, Alaska, Geologic Society Symposium Proceedings, p. Q1-Q23.

- Plafker, George, Bruns, T. R., and Page, R. A., 1975, Interim report on petroleum resources potential and geologic hazards in the outer continental she $1 f$ of the Gulf of Alaska Tertiary Province: U.S. Geolocical Survey Open-File Report 75-592, 74 p., 7 figures.

Rau, W. W., 1948, Foraminifera from the Porter Shale (Lincoln Formation), Grays Harbor County, W/ashington: Journal of Paleontology, v. 22, no. 2, p. 152-174, plates 27-31.

1951, Tertiary Foraminifera from the Willapa River valley of southwest Washington: Joumal of P-leontology, v. 25 , no. 4 , p. $417-453$, plates $63-67$.

- 1958, Stratigraphy and foraminiferal zonation in some of the Tertiary rocks of southwestern Washington: U.S. Geological Survey Oil and Gas Investigation Chart OC. 57,2 sheets.

Crevk Formation of southeastern Alaska: Cushman Foundation for Foraminifera Research Cont ibutions, v. 14 , part 4 , p. $135-145$, plates 12,13 .

1964, Foraminifera from the northern Olympic Peninsula, Washington: U.S. Geological Survey Professional Paper 374-G, p. G1-G33, 7 plates

-_ 1966, Stratigraphy and Foraminifera of the Satsop River area, southern Olympic Peninsula, Washington: Washington Division of Mines and Geology, Bulletin 53, 66 p. 
1967, Geology of the Wynoochee Valley quadrangle, Grays Harbor County, Washington: Washington Division of Mines and Geology, Bulletin 56, 51 p., map scale 1:62,500.

1970, Foraminifera, Stratigraphy, and paleoecology of the Quinault Formation, Point Grenville-Raft River coastal area, Washington: Washington Division of Mines and Geology Bulletin 62, 40 p., 3 plates.

Smith, P. B., 1963, Possible Pleistocene-Recent boundary in the Gulf of Alaska, based on benthonic Foraminifera: U.S. Geological Survey Professional Paper 475-C, Article 79, p. C73-C77.

Smith, R. K., 1970, Late glacial Foraminifera from southeast Alaska and British Columbia and a worldwide high northern latitude shallow-water faunal province: Archives des Sciences, v. 23, pt. 3, p. 675-701.

"Tappan, Helen, 1951, Northern Alaska index Foraminifera: Cushman Foundation for Foraminifera Research Contributions, v. 2, part 1, p. 1-8, plates 1, 2 .
Tipton, Ann, Kleinpell, R. M., and Weaver, D. W., 1973, Oligocene biostratigraphy, San Joaquin Valley, California: University of California Publications in Geological Sciences, v. 105, 81 p., 14 plates.

"Todd, Ruth, 1953, Foraminifera from the Lower Tertiary of Amchitka Island, Aleutian Islands: Cushman Fc'undation for Foraminifera Research Contributions, v. 4, part 1, p. $1-7$, plates $1,2$.

1957, Foraminifera from Carter Creek, northeastern Alaska: U.S. Geological Survey Professional Paper 294-F, p. F223-F235, plates 28, 29.

-Todd, Ruth, and Low, Doris, 1967, Recent Foraminifera from the Gulf of Alaska and southeastern Alaska : U.S. Geological Survey Professional Paper 573-A, p. A1-A46, plates 1-5.

White, W. R., 1956, Pliocene and Miocene Foraminife:a from the Capistrano Formation, Orange County, Calfornia: Journal of Paleontology, v. 30, no. 2, p. 237-260, plates 27-32. 
